\title{
POTENTIAL YIELD OF DEEP SEA SHRIMP RESOURCES IN THE SOUTHERN JAVA OF THE INDIAN OCEAN EEZ WATERS
}

\author{
Ali Suman ${ }^{1)}$, Muhammad Rijal'2), and Gatut Bintoro ${ }^{3)}$ \\ Research Institute for Inland Waters Fisheries, Mariana-Palembang \\ ${ }^{2)}$ Research Institute for Marine Fisheries, Muara Baru-Jakarta \\ 3) Politeknik Pertanian Negeri Pangkep, Sulawesi Selatan \\ Received April 21-2006; Received in revised form July 3-2006; Accepted June 26-2008
}

\begin{abstract}
Study on the potential yield of deep sea shrimp in the south off Java waters (Indian Ocean) was carried out based on data collected from the survey conducted between May and June 2005 using Baruna Jaya IV research vessel. This study was basically conducted by applying swept area method. The result showed that the population of deep sea shrimp in this area were Penaeid shrimp, Caridean shrimp, and Scampi. The species composition of deep sea shrimp were consist of 38 species and the catch of shrimp was dominated by scarlet shrimp (Plesiopenaeus edwardsianus) about $26.04 \%$ and stout red shrimp (Aristeus virilis) about 12.59\%. Distribution of this resources is more in east area (southern off Yogyakarta to Pacitan) and rarely at west area (southern off Cilacap to Kebumen). The highest abundance of deep sea resources were caught on the depth 200 until $500 \mathrm{~m}$ and the lowest on the depth 500 until $750 \mathrm{~m}$. Stock density this resources in this area ranged between 7.8 and $311.9 \mathrm{~kg} \mathrm{~km}^{-2}$ and the biomass in this area was 1,232 ton with potential yield was around 616 ton per year.
\end{abstract}

KEYWORDS: potential yield, deep sea shrimp, Indian Ocean

\section{INTRODUCTION}

Fisheries resources is national resource in Indonesia which has not been managed profesionally yet. As a result, there has no control exploiting this resource due to strong demand of the resource and huge increase of labour amount working in capture fisheries (Huseini, 2005). If sustainable management of the resource is not applied, sooner, or later sustainability of the resource is indanger. Moreover extinct of the stock is a matter of to occur.

Status of most shallow waters shrimp stock in Indonesia is now already fully or over exploited (Pusat Riset Perikanan Tangkap, 2003). This fact indicated that exploitation of the shallow waters shrimp stock should be strongly decreased. In order to stabilize shrimp production of Indonesia from year to year will step down. One of new shrimp stocks of Indonesia is deep sea shrimp.

Indonesia and Japanese Goverment have made an agreement to do research about deep sea shrimp stock in EEZ area of south off Java and west off Sumatera waters. This report discusses potential yield of the deep sea shrimp resources in south off Java waters. It hopes that the report will be usefull for study and development of the deep sea shrimp stock in Indonesia waters.

\section{MATERIALS AND METHODS}

Corresponding author:

J. Beringin 308 Mariana,Telp./Fax.(0711) 537194, E-mail: litkan@palembang.wasantara.net.id
Source of data was based on research done from May 2005 to June 2005 in Indian Ocean of south off Java waters using Baruna Jaya IV research vessel. Period of research was about 33 days. Depth of waters ranged from $200 \mathrm{~m}$ to $1,000 \mathrm{~m}$ (Figure 1). Fishing gear used was trawl with length of head rope about $31.6 \mathrm{~m}$ (Anonymous, 2005). Handling time of each station was 30 minutes and catch rate was calculated in $\mathrm{kg}$. Species identification was based on King (1986); Dall et al. (1990); Holthuis (1991); Carpenter \& Niem (1998).

Stock density was predicted by using formula introduced by Shindo (1973); Saeger et al. (1976); Sparre \& Venema (1992) namely:

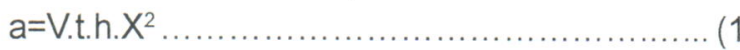

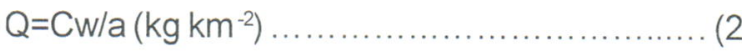

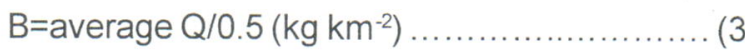

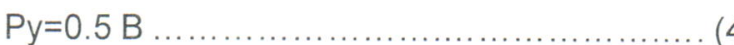

where:

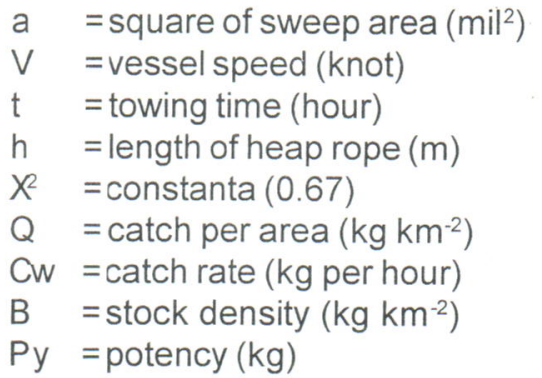




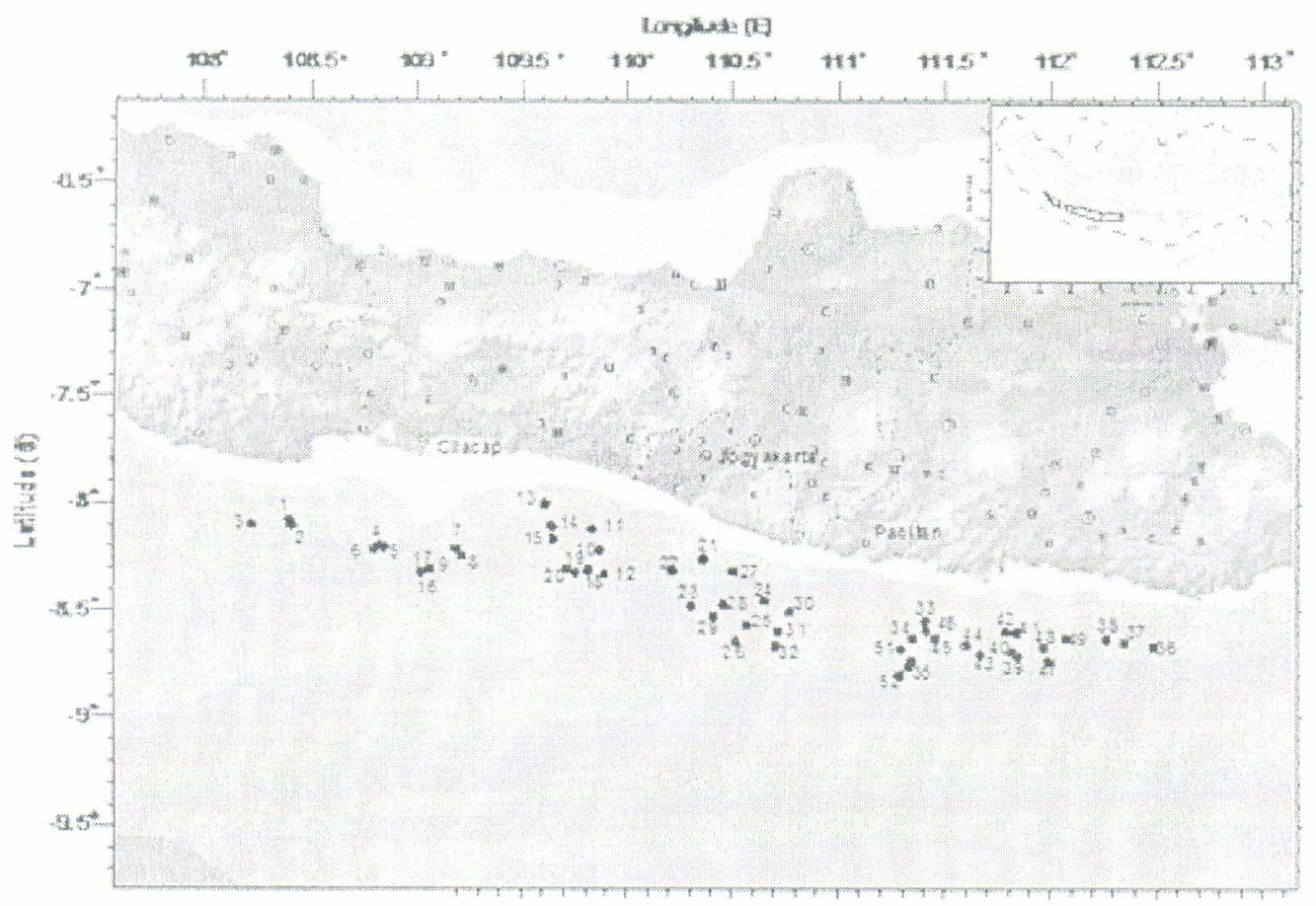

Figure 1. Sampling site of deep sea shrimp research in south off Java waters.

\section{RESULTSAND DISCUSSIONS}

\section{Species Composition}

Research found that total catch was $157.66 \mathrm{~kg}$ consisted of 38 species. Penaeid shrimp (Plesiopenaeus edwardsianus) dominated the catch while the least was deep sea lobster (Acanthacaris sp.) (Table 1). Table 1 showed that shrimp caught in south off Java waters was dominated by family of Penaeidae. This might be due to fishing ground where survey taken place was muddy waters. This condition was suitable habitat for commercial species such as Plesiopenaeus edwardsianus and Aristeus virilis (King, 1986). These species were also found in deep sea mud waters of Kai, Aru, and Tanimbar Islands (Sumiono \& Soselisa, 1993). Caridean shrimp (Heterocarpus $\mathrm{sp}$.) was another dominant species caught in coral waters of south off Yogyakarta and south off Pacitan (111-113 $\mathrm{BT}$ ). King (1986) informed that this species tended to live in coral waters. Sumiono \& Soselisa (1992) added that this species was also found in coral vaters of Kai, Aru, and Tanimbar Islands. Deep sea shrimp research in Pacific Island waters found that stock consisted of 16 Caridean shrimp which was dominated by Heterocarpus sp. dan Plesionika sp. (King, 1986). Another research about the deep sea shrimp stock in west off India waters found 13 species of Penaeid (George, 1967). In addition, most of the deep sea shrimp caught in Australia waters was family of Penaeidae such as Plesiopenaeus edwardsianus, Aristaemorpha foliacea, and Haliporoides spp. (Wadley \& Morris, 1991).

Table 2 showed that based on size, Plesiopenaeus edwardsianus, Aristeus virilis, $M$. andamanicus, and Heterocarpus sp. were categorized as big shrimp while Plesionika martia and Acanthephyra armata were classified as small shrimp. These dominant species were also categorized as important economic species (King, 1986).

Figure 2 also showed that size composition of the catch was highly varied. This informed that deep sea shrimp population consisted of several cohort. This also indicated that young and adult shrimp tended to live in one population. Investigation toward size of female and male shrimps indicated that the former always bigger than the later. This condition was identical with data obtained from research done in shallow waters (Naamin, 1984).

\section{Distribution}

Distribution of the deep sea shrimp is influenced by waters depth whereas each species tend to live in certain depth. It usually happens that the deeper of the waters, the bigger the size of deep sea shrimp (King, 1986). Table 2 showed that distribution of deep 
sea shrimp caught in south off Java waters. It was also informed that small deep sea shrimps family of Pandalidae and Penaeidae were distributed in shallow waters below $500 \mathrm{~m}$ while big deep sea shrimps family of Penaeidae such as $A$. virilis, $P$. edwardsianus (famili Aristeidae) tended to live in deeper waters (>500 m). There were also several species which could live in wide range of depth such as family of Aristeidae, Pandalidae, Sergestidae, and Solenoceridae. They distributed in 200 until 1,000 m. Research in Australia waters found that $P$. edwardsianus, A. foliacea, and $H$. sibogae spreaded from 350 until $750 \mathrm{~m}$ while Haliporoides spp. tended to stay in the depth of 275 until $820 \mathrm{~m}$ (Holthuis, 1980). The deep sea shrimps stated in Table 2 were also found in Kai, Aru, and Tanimbar waters (Sumiono \& Soselisa, 1993). Another previous research reported that Solenocera spp., Hymenopenaeus spp., Metapenaeopsis spp., and Parapenaeus spp. were also found in east of Indonesian waters (George, 1967).

In general, $P$. edwardsianus, $A$. armata, and $A$. virilis had the widest area of distribution because they had the highest frequency of occurrence, namely 71 , 67 , and $65 \%$ respectively (Tabel 2 ). Same phenomenon was found in Kai, Aru, and Tanimbar waters. The widest area of distribution was occupied by family Aristeidae and Pandalidae (Sumiono \& Soselisa, 1993). According to waters depth, the deep sea shrimp in EEZ area of south off Java waters was mostly caught in the depth in the depth 200 to $500 \mathrm{~m}$ (Figure 3).

In Australia deep sea waters, most of the deep sea shrimp was found at depth of 300 to $500 \mathrm{~m}$ (Wadley \& Morris, 1991). Similarly in Kai, Aru, and Tanimbar waters, most of them was caught in 400 to $500 \mathrm{~m}$ depth (Sumiono \& Soselisa, 1993).

Table 1.

Species composition of deep sea shrimp in the southern Java of the Indian Ocean EEZ waters

\begin{tabular}{lclc}
\multicolumn{1}{c}{ Species/Family } & Percentage (\%) & \multicolumn{1}{c}{ Species/Family } & Percentage (\%) \\
\hline Aristaeomorpha foliacea & 0.12 & Heterocarpus sp.1 & 6.94 \\
Aristeus virilis & 12.59 & Heterocarpus sp.2 & 0.83 \\
Plesiopenaeus edwardsianus & 26.04 & Heterocarpus sp.3 & 0.54 \\
Acanthacaris sp. & 0.00 & Heterocarpus sp.4 & 0.01 \\
Metanephrops andamanicus & 12.34 & Parapandalus serratifrons & 0.10 \\
Metanephrops neptunus & 0.35 & Plesionika ensis & 1.61 \\
Nephrops stewaili & 0.56 & Plesionika longirostris & 4.94 \\
Nephrops sp. & 0.15 & Plesionika martia & 7.22 \\
Linuparus sordidus & 0.58 & Plesionika sp. & 0.02 \\
Puerulus angulatus & 0.26 & Parapenaeus fissurus & 1.36 \\
Puerulus velutinus & 0.27 & Penaeopsis eduardoi & 3.29 \\
Acanthephyra armala & 4.82 & Penaeopsis rectacuta & 0.02 \\
Acanthephyra sp. & 0.04 & Acetes sp. & 1.96 \\
Eugonatonotus sp. & 0.00 & Sergestes sp. & 0.50 \\
Heterocarpus dorsalis & 0.81 & Haliporoides sibogae & 0.51 \\
Heterocarpus gibbosus & 0.51 & Solenocera alfonso & 2.33 \\
Heterocarpus laevigatus & 0.58 & Solenocera choprai & 0.37 \\
Heterocarpus sibogae & 0.87 & Solenocera melantho & 0.01 \\
Heterocarpus sp. & 3.73 & Solenocera sp. & 2.81
\end{tabular}

\section{Stock Density and Potential Yield}

Data of stock density were shrimp collected from 52 research stations located in between south off east Java and south of west Java waters (Figure 1). The highest stock density was $398,98 \mathrm{~kg} \mathrm{~km}^{-2}$ found in station 24 at area 110 to $111^{\circ} \mathrm{E}$ in south off Yogyakarta until Pacitan waters. While the lowest was $7,83 \mathrm{~kg}$ $\mathrm{km}^{-2}$ caught in station 20 at area $109-110^{\circ} \mathrm{E}$ in south off Cilacap until Kebumen waters. This was higher than that in EEZ area of south off Irian Jaya waters which the highest only $7,9 \mathrm{~kg} \mathrm{~km}^{-2}$ (Suman et al., 1993). The detailed information about stock density in south off Java waters was shown at Table 3.

Table 3 informed that average stock density was higher in east area with the highest stock density in area of $110-111^{\circ} \mathrm{E}$. This was area J-3 located in south of Yogyakarta and Pacitan waters. This phenomenon might be caused by suitability of this habitat for most dominant of deep sea shrimp (family Aristeidae) which tended to live in mud waters (King, 1986). 

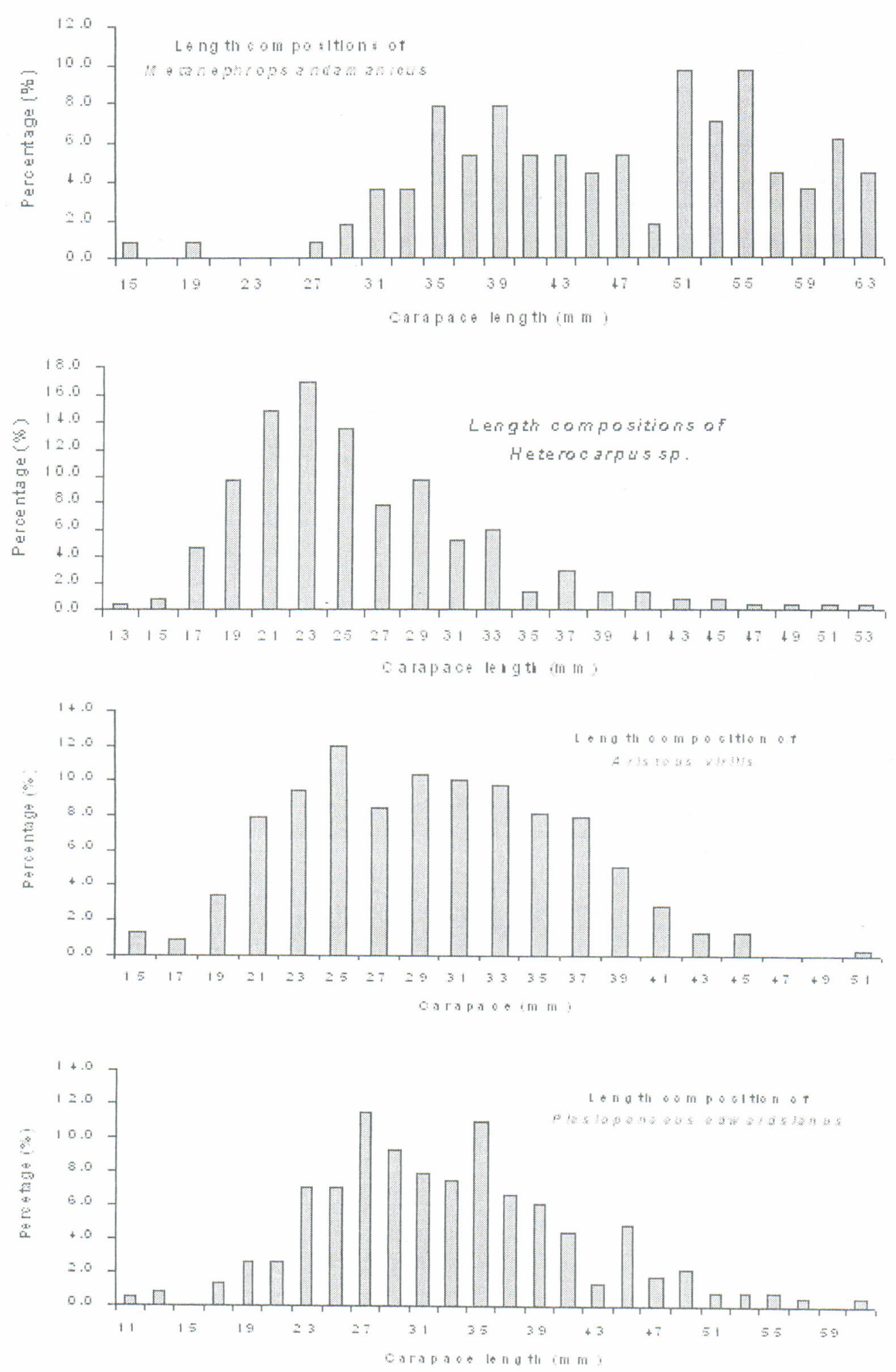

Figure 2. Length composition of dominant species of shrimps in southern of Java waters. 
Potential Yield of Deep Sea .... in the Southern Java of the Indian Ocean EEZ Waters (Suman, A., et al.)

Table 2. Distribution of deep sea shrimp in the southern Java of the Indian Ocean EEZ waters

\begin{tabular}{|c|c|c|c|c|}
\hline \multirow{2}{*}{ Species/Family } & \multicolumn{3}{|c|}{ Depth $(m)$} & \multirow{2}{*}{ Occ. $(\%)$} \\
\hline & $200-500$ & $500-750$ & $750-1000$ & \\
\hline \multicolumn{5}{|l|}{ Aristeidae } \\
\hline Aristaeomorpha foliacea & - & $x x x x$ & $x x x x$ & 4 \\
\hline Aristeu virillis & $x x x x$ & $x X X X$ & $x x x x$ & 65 \\
\hline Plesiopenaeus edwarsianus & $x x x x$ & $x x x x$ & $x x x x$ & 71 \\
\hline Nephropidae & & & - & \\
\hline Acanthacaris sp. & - & - & $x x x x$ & 2 \\
\hline Metanephrops andamanicus & $x x x x$ & $x x x x$ & - & 27 \\
\hline Metanephrops neptunus & - & $x x x x$ & - & 8 \\
\hline Nephrops stewati & $x x x x$ & $x x x x$ & $x x x x$ & 13 \\
\hline Nephrops sp. & - & $x x x x$ & $x x x x$ & 13 \\
\hline \multicolumn{5}{|l|}{$\begin{array}{l}\text { Nephrops sp. } \\
\text { Palinuridae }\end{array}$} \\
\hline Linuparus sordidus & $x x x x$ & - & - & 2 \\
\hline Puerulus angulatus & $x x x x$ & $x x x x$ & - & 8 \\
\hline Puerulus velutinus & - & $x x x x$ & - & 2 \\
\hline \multicolumn{5}{|l|}{ Pandalidae } \\
\hline Acanthephyra armata & $x x x x$ & $x x x x$ & $x x x x$ & 67 \\
\hline Acanthephyra sp. & - & $x x x x$ & - & \\
\hline Eugonatonotus sp. & - & - & $x x x x$ & 2 \\
\hline Heterocarpus dorsalis & $x x x x$ & $x x x x$ & $x x x x$ & 48 \\
\hline Heterocarpus gibbosus & $x x x x$ & $x x x x$ & $x x x x$ & 15 \\
\hline Heterocarpus laevigatus & $x x x x$ & $x x x x$ & $x x x x$ & 21 \\
\hline Helerocarpus sibogae & $x x x x$ & $x x x x$ & $x x x x$ & 29 \\
\hline Heterocarpus sp. & - & $x X X X$ & $x x x x$ & 33 \\
\hline Heterocarpus sp.1 & $x x x x$ & $x x x x$ & $x x x x$ & 54 \\
\hline Heterocarpus sp.2 & - & $x x x x$ & $x x x x$ & 14 \\
\hline Heterocarpus sp. 3 & $x x x x$ & $x x x x$ & $x x x x$ & 12 \\
\hline Heterocarpus sp.4 & - & $x x x x$ & - & 2 \\
\hline Parapandalus serratifrons & $x x x x$ & $x x x x$ & - & 6 \\
\hline Plesionika ensis & $x x x x$ & $x x x x$ & - & 23 \\
\hline Plesionika longirostris & $x x x x$ & $x x x x$ & $x x x x$ & 17 \\
\hline Plesionika martia & $x x x x$ & $x x x x$ & - & 23 \\
\hline Plesionika sp. & - & - & $x x x x$ & 2 \\
\hline \multicolumn{5}{|l|}{$\begin{array}{l}\text { Plesionika sp. } \\
\text { Penaeidae }\end{array}$} \\
\hline Parapenaeus fissurus & $x x x x$ & - & - & 6 \\
\hline Penaeopsis eduardoi & $x x x x$ & - & - & 10 \\
\hline Penaeopsis rectacuta & $x x x x$ & - & - & 4 \\
\hline \multicolumn{5}{|l|}{$\begin{array}{l}\text { Penaeopsis rectacuta } \\
\text { Sergestidae }\end{array}$} \\
\hline Acetes sp. & $x x x x$ & $x x x x$ & $x x x x$ & 54 \\
\hline Sergestes sp. & $x x x x$ & $x x x x$ & $x x x x$ & 31 \\
\hline \multicolumn{5}{|l|}{$\begin{array}{l}\text { Sergestes sp. } \\
\text { Solenoceridae }\end{array}$} \\
\hline Haliporoides sibogae & $x x x x$ & $x x x x$ & $x x x x$ & 15 \\
\hline Solenocera alfonso & $x x x x$ & $x x x x$ & $x x x x$ & 50 \\
\hline Solenocera choprai & $x x x x$ & $x x x x$ & - & 4 \\
\hline Solenocera melantho & $X x x x$ & - & - & 2 \\
\hline Solenocera sp. & $X x x x$ & $X x x x$ & $x x x x$ & 58 \\
\hline
\end{tabular}


South off Java waters

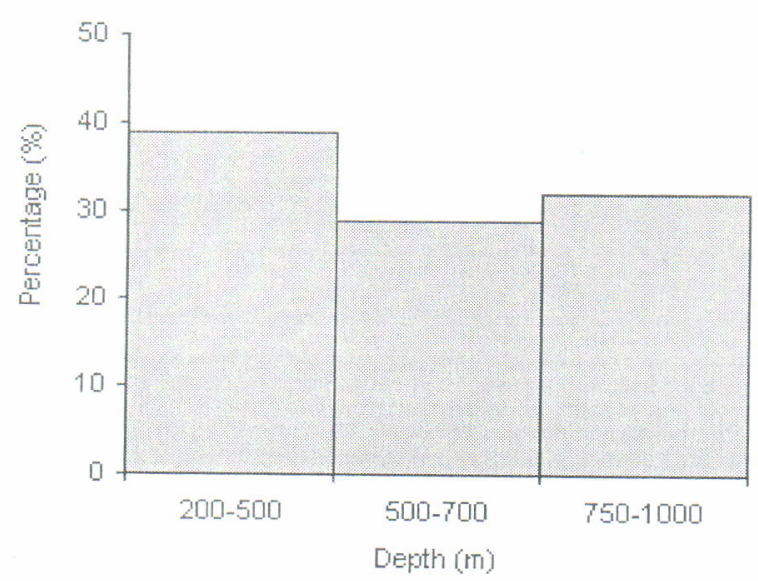

Figure 3. Vertical distribution of deep sea shrimp in the southern Java of the Indian Ocean EEZ waters.

Tabel 3. Stock density of deep sea shrimp $\left(\mathrm{kg} \mathrm{km}^{-2}\right)$ in the southern Java of the Indian Ocean EEZ waters

\begin{tabular}{|c|c|c|c|}
\hline Station & Stock density $\left(\mathrm{kg} \mathrm{km}^{-2}\right)$ & Station & Stock density $\left(\mathrm{kg} \mathrm{km}^{-2}\right)$ \\
\hline 1 & 46.81 & 28 & 66.69 \\
\hline 2 & 89.36 & 29 & 39.59 \\
\hline 3 & 108.49 & 30 & 248.75 \\
\hline 4 & 23.08 & 31 & 118.81 \\
\hline 5 & 47.15 & 32 & 184.2 \\
\hline 6 & 64.24 & 33 & 211.57 \\
\hline 7 & 32.37 & 34 & 183.15 \\
\hline 8 & 114.66 & 35 & 100.43 \\
\hline 9 & 143.18 & 36 & 95.56 \\
\hline 10 & 53.79 & 37 & 112.85 \\
\hline 11 & 93.21 & 38 & 120 \\
\hline 12 & 83.4 & 39 & 88.17 \\
\hline 13 & 215.01 & 40 & 116.15 \\
\hline 14 & 84.87 & 41 & 101.45 \\
\hline 15 & 120.95 & 42 & 112 \\
\hline 16 & 106.25 & 43 & 56.27 \\
\hline 17 & 92.66 & 44 & 121.7 \\
\hline 18 & 13.62 & 45 & 57.19 \\
\hline 19 & 53.65 & 46 & 88.51 \\
\hline 20 & 7.83 & 47 & 68.26 \\
\hline 21 & 285.11 & 48 & 12.87 \\
\hline 22 & 9.53 & 49 & 122.55 \\
\hline 23 & 92.26 & 50 & 62.5 \\
\hline 24 & 398.98 & 51 & 62.13 \\
\hline 25 & 17.09 & 52 & 86.98 \\
\hline $\begin{array}{l}26 \\
27\end{array}$ & $\begin{array}{l}131.27 \\
199.83\end{array}$ & Average & 103.15 \\
\hline
\end{tabular}

Based on data collection from 52 research stations, total biomass (standing stock) of deep sea shrimp in south off Java was predicted to be 1,137 ton. Because no exploitation in this area, potential yield of deep sea shrimp would be a half of total biomass, namely
568 ton per year. Total biomass and potential yield of deep sea shrimp resources in this area were much more higher than that in south off Irian Jaya waters which were only 553 ton and $=7$ ton respectively. According to the potential yielc. and existing condition 
of exploitation in south off Java waters, about 250 fishing units can be operated to exploit the deep sea shrimp resources. Therefore there is a good chance for fishermen in south off Java waters especially who have fishing base in Cilacap, Yogyakarta, and Pacitan operating new fishing units in order to get benefit from exploiting the deep sea shrimp reșources.

\section{CONCLUSSION AND RECCOMENDATION}

1. There were 38 species of the deep sea shrimps found in south off Java waters. scarlet shrimp ( $P$. edwardsianus) dominated the catch $(26.04 \%)$ and most of the catch was categorized as commercial species.

2. The highest distribution of deep sea shrimp was found in 200 to $500 \mathrm{~m}$ and $P$. edwardsianus, A. armata and $A$. virilis had the widest area of distribution.

3. The bigger size of deep sea shrimp was caught in the depth 500 to $1,000 \mathrm{~m}$ and the smaller size was found in the depth 200 to $500 \mathrm{~m}$.

4. Stock density of the deep sea shrimp in south off Java waters ranged from 7.83 to $398.98 \mathrm{~kg} \mathrm{~km}^{-2}$ and stock density in east area of south off Java waters was higher than that in west area.

5. Total biomass (standing stock) and potential yield of deep sea shrimp in south off Java waters were 1,137 ton and 568 ton respectively.

6. Support from local government in south of Java area was urgently required in order to provide fishermen with 250 fishing units to exploit the deep sea shrimp resources in south off Java waters.

\section{ACKNOWLEDGEMENTS}

This paper was part of joint research project between Indonesia and Japan, F.Y. 2005, The title of research is stock of deep sea demersal fish resources.

\section{REFERENCES}

Anonymous. 2005. The Japan-Indonesia deep sea fishery resources joint exploration project (Report of 2004 Field Survey). Overseas Fishery Cooperation Foundation-Research Institute for Marine Fisheries.

Carpenter, K. E. 7 V. H. Niem (Eds.). 1998. FAO identification guide for fishing purpose. The Living
Marine Resources of the Western Central Pacific. Vol.2. Chepalopods, Crustaceans, Holothurians, and Sharks. FAO Rome.

Dall, W., B. J. Hill, P. C. Rothlisberg, \& D. J. Staples 1990. The biology of the Penaeidae. In Blaxter, J. H. S \& A. J. Southward (eds.): Marine Biology. Vol.27. Academic Press. London, San Diego, New York, Boston, Sydney, Tokyo, Toronto. 489 p.

George, M. J. 1967. On a collection of Penaeid prawns from the offshore water of the south-west India. In Proceeding of symposium on crustacea. Part 1. p. 337-344.

Holthuis, L. B. 1980. FAO species catalogue. Vol.1. Shrimps and prawns of the world. An annotated catalogue of species interest to fisheries. FAO Fishery Synopsis. (12.5). Vol.1. 261 p.

Holthuis, L. B. 1991. FAO species catalogue. Vol.13. Marine lobsters of the world. An annotated and illustrated catalogue of species interest to fisheries know to date. FAO Fishery Synopsis. (125). Vol.13. 292 p.

Huseini, M. 2005. Antara produksi dan pemasaran harus sinergi. Majalah SAMUDERA. Edisi Juli tahun III. p. 8.

King, M. J. 1986. Deep-water shrimps. The fishery resources of Pacific Island countries. Part I FAO Fish. Tech. Pap. (272.1). 45 p.

Naamin, N. 1984. Dinamika populasi udang jerbung (Penaeus merguiensis de Man) di perairan Arafura dan alternatif pengelolaannya. Disertasi Doktor pada Fakultas Pasca Sarjana. Institut Pertanian Bogor. Bogor.

Pusat Riset Perikanan Tangkap. 2003. Sumber daya udang laut di Indonesia: Potensi dan tingkat pemanfaatannya. Pusat Riset Perikanan Tangkap. Badan Riset Kelautan dan Perikanan. 15 hal.

Saeger, J., P. Martosubroto, \& D. Pauly. 1976. Fish report of the Indonesia German demersal fisheries project. Result of a trawl survey in the Sunda Shelf area. Laporan Penelitian Perikanan Laut. No.1. $1-46$.

Shindo, S. 1973. General review of the trawl fisheries and the demersal fish stock of the South China Sea. FAO Fish. Tech. Pap. No.120. FAO, Rome. 
Sparre, P. \& S. C. Venema. 1992. Introduction to tropical fish stock assesment. Part I. Manual. FAO Fish Tech. Pap. No.306/1.

Suman, A., S. Budihardjo, \& A. P. Anung W. 1993. Stok sumber daya udang di perairan ZEE selatan Irian Jaya. Jurnal Penelitian Perikanan Laut. No.79. 92-98.
Sumiono, B. \& J. Soselisa. 1993. Udang laut dalam di perairan Kai dan Tanimbar (bagian 1: Jenis-jenis udang dan penyebarannya. Jurnal Penelitian Perikanan Laut. No.73

Wadley, V. A. \& S. L. Morris. 1991. Deep water fishery for prawn and carids off Western Australia. In Davie, P. J. S. \& R. H. Quinn (Eds). Memoirs of the Queensland Museum. Published by order of the board Vol.31. 466. 